Ye. O. Mishchuk, orcid.org/0000-0002-7850-0975,

I. I. Nazarenko, orcid.org/0000-0002-1888-3687, D.O. Mishchuk, orcid.org/0000-0002-8263-9400
Kyiv National University of Construction and Architecture, Kyiv, Ukraine, e-mail: mischuk.ieo@knuba.edu.ua

\title{
DEFINITION OF RATIONAL OPERATING MODES OF A VIBRATORY JAW CRUSHER
}

Due to the continuous development of the building-and-construction industry, it is necessary to design new or modify outmoded industrial equipment. Using jaw crushers with the impact action of crushing plates on material is a perspective line of developing crushing equipment.

Purpose. Developing a mathematical model of a vibratory jaw crusher and studying the operational process which is based on the mathematical model in order to design new crushers.

Methodology. Definition of the crusher working process is based on the main statements of the theory of mechanical oscillations and the theory of continuous environment. In the motion equations of the crusher the material is taken into account on the basis of a discrete model by a continual parameter.

Findings. A physical model is developed on the basis of which motion equations are derived, which include three main conditions of the efficient operation: 1) the elasticity of the second vibrating element must exceed or be equal to crushing force; 2) vibrations of the first and the third vibrating elements must be in phase, and vibrations of the second vibrating element must be in antiphase; 3 ) the summarized displacement of the second and the third crushing plates must ensure crushing of material. Graphs of the effect of the vibrating elements and elasticity coefficients of elastic systems on the amplitudes of vibrations are plotted and analyzed. On the basis of the motion equations, with consideration for the optimal parameters of the crusher vibrating elements and for the elasticity coefficients of the elastic systems, the amplitude-frequency characteristics of the crusher for different frequency ranges are determined. Set up is an equation describing the displacement of material in the crushing chamber for a time interval required for the crushing plates to be separated. Presented are graphs of dependency of the amplitude of vertical vibrations of the crusher casing on the elasticity of the isolating elastic system, and provided are recommendations for selecting and calculating vibration isolation.

Originality. A mathematical model of an experimental vibratory jaw crusher and the characteristics of the experimental crusher are presented, on the basis of which recommendations are given for the selection of energy-efficient operating modes of the crusher.

Practical value. Knowledge on the rational values of the frequency ranges for operation of the studied vibratory jaw crusher makes it possible to determine the optimal level of power consumed by the crusher and efficiency in processing materials of different hardness.

Keywords: vibratory jaw crusher, elasticity coefficient, energy efficiency, vibration frequency, excitation force

Introduction. Due to the continuous development of the building-and-construction industry, it is necessary to design new or modify outmoded industrial equipment. To a considerable extent, this statement applies to crushing and screening equipment. This is caused by the fact that significant part of power resources is consumed by such equipment, operating at quarries and construction plants, in connection with production and processing of construction materials. For example, in production and processing of construction materials, the annual electric power consumption is about 20 percent of the total electric power produced in Ukraine, and metal consumption is about 2.5 percent of the total metal produced in Ukraine. Operational costs for crushing and screening equipment are also considerable.

Jaw crushers pertain to the most commonly encountered equipment for crushing construction materials and are known as the most power-consuming equipment. Nevertheless, using jaw crushers for crushing construction materials is efficient because such crushers allow processes of crushing, abrasion, and, in special conditions, impact grinding to be combined.

Jaw crushers with the impact action of crushing plates on material being processed are perspective as crushing equipment. Vibratory jaw crushers are designed as crushers with impact action of crushing plates on material. But the practical use of such crushers is limited due to the insufficient study on interaction between the crusher actuator and material being processed. The stable resonance vibration modes of the crush-

(c) Mishchuk Ye. O., Nazarenko I. I., Mishchuk D. O., 2021 er are determined insufficiently. The ranges of the crusher parameter values that are required for ensuring the stable crusher operation have not been determined.

Solving this problem is possible by using new methods for simulating and studying operational process and determining optimal operating modes for vibratory jaw crushers.

Literature review. Vibration machines for the building and construction industry were implemented in the last century. Those machines had essentially one or two vibrating elements. Such machines were widely used for compaction of concrete mixtures in the manufacture of elements of building structures. The advantage of vibration machines consists in the possibility to operate the machine in a resonance vibration mode. In this mode, power consumed by the machine is significantly reduced, and vibration amplitudes of the crusher vibrating elements are increased.

The further development of vibration machines consisted in designing energy-efficient vibration machines with three vibrating elements and in implementing electromagnetic and pneumatic vibration exciters. Studied in paper [1] is a vibratory compacting machine with an electromagnetic vibration exciter. In this vibration machine, two related vibrating elements (a reactive element and an intermediate element) vibrate in phase, and the third vibrating element (an active element) vibrates in anti-phase to the vibrations of the first and second elements. The excitation force is generated by a pushpull electromagnetic vibration exciter. All the three vibrating elements are connected with each other by elastic connecting elements. The total elasticity of the elastic connecting element is determined as follows 


$$
c_{2}=m_{p}\left(\frac{\omega}{z}\right)^{2} \eta,
$$

where $m_{r}$ is the weight of the reactive element; $w$ is the forced vibration frequency; $z$ is the resonance frequency of the elastic connecting element as a mechanical system; $\eta$ is the relative part of the total elasticity $c_{2}$ that represents the bending elasticity of the elastic connecting element.

In such elastic connecting elements, when the value $\mathrm{h}$ is close to 1 , the vibration amplitude significantly increases. The advantage of the vibration machines according to paper [1] consists in lower power consumption as compared with vibration machines with traditional electromagnetic vibration exciters, which is possible due to reduced air gap in the electromagnetic vibration exciter. The disadvantage consists in higher dissipative losses and significant power consumption.

Paper [2] contains the results of the studies on a vibratory jaw crusher with two movable crushing plates. The studies were performed in order to determine the possibility to decrease power consumed by the crusher and increase the productivity of the crusher by implementing the rated crusheroperating mode with compensation of excitation power. The compensation is provided by the automatic control system that controls the crusher operation according to a phase shift angle between vibrations of the crushing plates. The crusher contains two movable crushing plates, which are connected with an unbalance vibration exciter by links. The movable crushing plates are suspended on torsion shafts. Crushers of this type are rated for a rotation frequency of 800-1500 rpm. As compared with eccentric jaw crushers, vibratory jaw crushers with two movable crushing plates have the following advantages: 1. Power consumption is reduced by $20-30$ percent. 2. Granularity of crushed material is not lower than 8 units. 3 . The quality of crushed material is higher.

The disadvantage of such crushers is that the crusher productivity is reduced by a factor of about 4 . Therefore, it is reasonable to use such crushers for processing hard and super hard materials.

On the basis of the studies described in paper [2], it is determined that increase in the initial phase difference between vibrations causes decrease in the crusher productivity, increase in power consumption, and irregular operation of the crusher driving motors. When the crusher operates in the mode with synchronous - antiphase vibrations, the phase difference between vibrations can be eliminated by controlling such parameters of the driving motors as $\omega_{0}$ and $\beta$ provided that the difference between the motor rotation frequencies $\Delta \omega_{m}=0$. According to the experimental results, the crusher productivity can be increased by 87 percent. In the paper, there is no information about to what extent the power consumption could be changed.

Partially, the problem in connection with increasing productivity of vibratory jaw crushers is discussed in paper [3] by the example of an experimental vibration jaw crusher with an inclined crushing chamber and two movable crushing plates. The experimental data obtained demonstrate that the crusher productivity is $2.7-3$ times the productivity of a crusher with a vertical crushing chamber. In this case, the granularity of processed material almost does not change.

When studying the parameters of a vibratory jaw crusher with inclined crushing plates, which is discussed in paper [3], it is determined that the stable operating mode of the crusher is ensured at a vibration frequency of $23-30 \mathrm{~Hz}$. At frequencies over $30 \mathrm{~Hz}$, the crushing process is interrupted due to antisymmetric resonance. At frequencies under $23 \mathrm{~Hz}$, the reduced rate of delivery and excessive crushing of material are observed. As is stated in the paper, in a frequency range of 23$30 \mathrm{~Hz}$, the crusher productivity increases by a factor of 1.5 as compared with vibratory crushers with a vertical crushing chamber. When the vibration frequency is close to $30 \mathrm{~Hz}$, material granularity Is reduced twofold.
Paper [4] contains the results of studies based on the known wave equation that describes the motion of material in the crushing chamber without considering energy dissipation. To determine stresses in the crushing chamber, standard methods are used.

The author of paper [4] presents the experimental data obtained for the crusher operation in a narrow vibration frequency range of $27-35 \mathrm{~Hz}$, because the maximum crusher productivity is ensured in this frequency range. In the paper, there is no data obtained for other frequency ranges and no data on power consumption.

Paper [5] contains experimental data concerning the process of crushing material with different hardness values by using a KW 40/1 vibratory jaw crusher with two movable crushing plates. Materials to be processed include lime, dolomite, diabase, quartzite, and ceramic waste. On the basis of the experimental data, it is determined that the processing of raw material with fractions of $0-50 \mathrm{~mm}$ can result in $60-90$ percent of final material with fractions of $0-2 \mathrm{~mm}$. Additionally, the paper contains information about the frequencies at which corresponding materials were processed, and contains no information about reasons for using these frequencies. There is no information about the adjustment of the crusher for operation in the specified frequency range in order to process materials with different hardness values in the crushing chamber. It is the author's opinion that this vibratory jaw crusher allows the number of grinding machines at the processing plant to be reduced.

As is described in paper [6], a KW 40/1 vibratory jaw crusher is used for crushing rock crystal at the fixed frequency of the crushing plate vibrations equal to $f=18 \mathrm{~Hz}$. As a result, more than 95 percent of the processed material have particles in size not more than $5 \mathrm{~mm}$, and 30 percent of the processed material have particles in size not more than $1 \mathrm{~mm}$. The paper does not contain information about the power consumed by the crusher and the productivity of the crusher.

The results of the theoretical studies on a vibratory jaw crusher with a massive casing and a pendulum actuator are presented in paper [7]. The diagrams that describe the motions of the movable crushing plates are plotted by using the RungeKutta method. The effect of the crusher dynamic parameters on final processed material is determined. The study results presented in this paper are reliable so far as the parameter values are accurate, and the crusher design characteristics are considered.

Paper [8] contains data on the theoretical and experimental studies on a shock-and-vibration cone crusher with two self-synchronizing vibration exciters, which are installed in the crusher casing symmetrically to the vertical axis of the crusher. In the paper, the equations describing the motions of the crusher vibrating elements and the amplitude-frequency characteristics of the crusher vibrating elements are presented. The crusher is designed for processing electrocorundum. The amplitude-frequency characteristics demonstrate that the frequency of the antiphase vibrations of the crushing cone and crushing chamber $\omega>117 \mathrm{rad} / \mathrm{s}$. The crusher productivity is $4400 \mathrm{~kg} / \mathrm{h}$.

Paper [9] contains data on the study on a shock-and-vibration cone crusher with two degrees of freedom. The mathematical model of the crusher is developed with consideration for bilinear hysteresis in the nonlinear equations for the crusher vibrating elements. The characteristics obtained in the study demonstrate a slight difference between the calculated parameter values and actual parameter values obtained during the crusher operation.

Purpose. The purpose of this paper consists in justifying the mathematical model of a vibratory jaw crusher and studying the operational process of the crusher in order to use the study results for designing new crushers.

Methods. According to this purpose, the following tasks should be performed: 
1. To develop the physical and mathematical models of the vibratory jaw crusher.

2. To determine and analyze the ranges of parameters and operating modes of the crusher.

3. To determine the optimal values of the basic crusher parameters.

Results. When developing the vibratory jaw crusher, it is necessary to fulfill the following conditions for the design of the crusher: 1. High productivity. 2. Stability of operation in modes close to the resonance vibration modes. 3. Low power consumption

For the further studies, the physical model of the vibratory jaw crusher (Fig. 1) was developed.

The vibratory jaw crusher to be studied is presented as a resonance system with three vibrating elements (Fig. 1). The first vibrating element is vibration exciter 1 with a support plate. The second vibrating element is unfixed casing 3 . The third vibrating element is the central plate with internal cover strips 5 . Each vibrating element is rated for horizontal vibrations along $X$ axis with coordinates $x_{1}, x_{2}$, and $x_{3}$ and inertial masses $m_{1}, m_{2}$, and $m_{3}$ correspondingly.

The active vibrating element is driven by a centrifugal force $F(t)=F_{0} \cdot \sin \omega t$ generated by rotation of the unbalance elements of the vibration exciter.

The crusher is adjusted so that vibrations of the first and the second vibrating elements are in phase, and vibrations of the third vibrating element are in antiphase to the vibrations of the first and the second vibrating elements.

All the vibrating elements of the crusher are connected by elastic elements 2 and 4 (Fig. 1) with elasticity coefficients $c_{1}$ and $c_{2}$. The crusher is isolated from the foundation by vibration isolators with an elasticity coefficient $c_{\text {sup }}$. The vibration isolators support the second vibrating element. In the crusher system, there are resisting forces, which are neglected in the analysis in order to simplify calculations.

The motion equations for the crusher system are based on the Hamilton principle. Analyzed were two states of the crusher in operation, that is, the state with material in the crushing chamber and the state without material in the crushing chamber. The results of the analysis of the process of crushing material in the crushing chamber are presented in paper [10].

As a result of mathematical transformations and differentiation, the following two equation systems were obtained:

1. For the state of the crusher without material in the crushing chamber

$$
\left\{\begin{array}{l}
m_{1} \ddot{x}_{1}+2 x_{1} c_{1}-x_{2} c_{1}=F_{0} \sin \omega t \\
m_{2} \ddot{x}_{2}+x_{2} c_{1}-x_{1} c_{1}+2 c_{2} x_{2}-2 c_{2} x_{3}+x_{2} c_{\text {sup }}=0 . \\
m_{3} \ddot{x}_{3}+2 c_{2} x_{3}-2 c_{2} x_{2}=0
\end{array}\right.
$$

2. For the state of the crusher with material in the crushing chamber

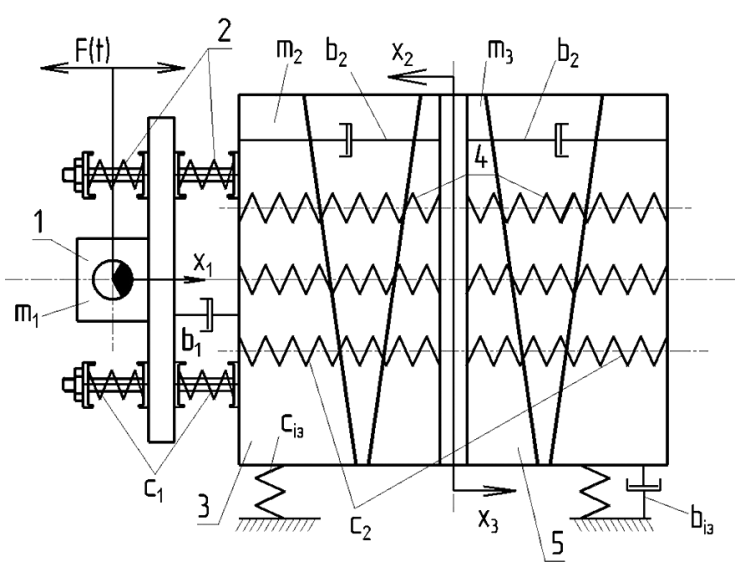

Fig. 1. Physical model of the vibratory jaw crusher

$$
\left\{\begin{array}{l}
m_{1} \ddot{x}_{1}+2 x_{1} c_{1}-x_{2} c_{1}=F_{0} \sin \omega t \\
\left(m_{2}+k m_{m}\right) \ddot{x}_{2}+x_{2} c_{1}-x_{1} c_{1}+2 c_{2} x_{2}-2 c_{2} x_{3}+x_{2} c_{\text {sup }}=0 \\
\left(m_{3}+k m_{m}\right) \ddot{x}_{3}+2 c_{2} x_{3}-2 c_{2} x_{2}=0
\end{array}\right.
$$

where $m_{m}$ is the weight of material; $k$ is the attached weight coefficient.

In order to ensure efficient operation of the crusher, it is necessary to fulfill the following three conditions [14] additionally to solving equation systems $(2,3): 1)$ The elasticity of the second vibrating element must exceed crushing force $F_{c r}$, that is, $-c_{2} x n \geq F_{c r} ; 2$ ) vibrations of the first and the third vibrating elements must be in phase, and vibrations of the second vibrating element must be in antiphase to the vibrations of the first and the third vibrating elements, that is $-x_{1}>0 ; x_{3}>0$ and $x_{2}<0 ; 3$ ) The summarized displacement of the second and the third crushing plates must ensure crushing of material, that is, $x_{2}+x 3 \geq \zeta * D_{\max }$.

On the basis of equation systems $(2,3)$, the effect of the elasticity coefficients of the elastic connecting elements on the vibration amplitudes of the vibrating elements was analyzed.

The equation for determining the elasticity coefficients of the elastic connecting elements is the following

$$
c_{i j}=\left(\omega_{0} n\right)^{2} \frac{m_{i} m_{j}}{m_{i}+m_{j}},
$$

where $\omega_{0}$ is the natural vibration frequency (resonance frequency); $n$ is the coefficient related to the ratio between elasticity and vibration frequency.

The corresponding graphs are presented in Fig. 2.

From (4), it is evident that the elasticity of each of the elastic connecting elements of the crusher system depends on element weight and vibration frequency. By varying these parameters, it is possible to select the optimal values of the elasticity
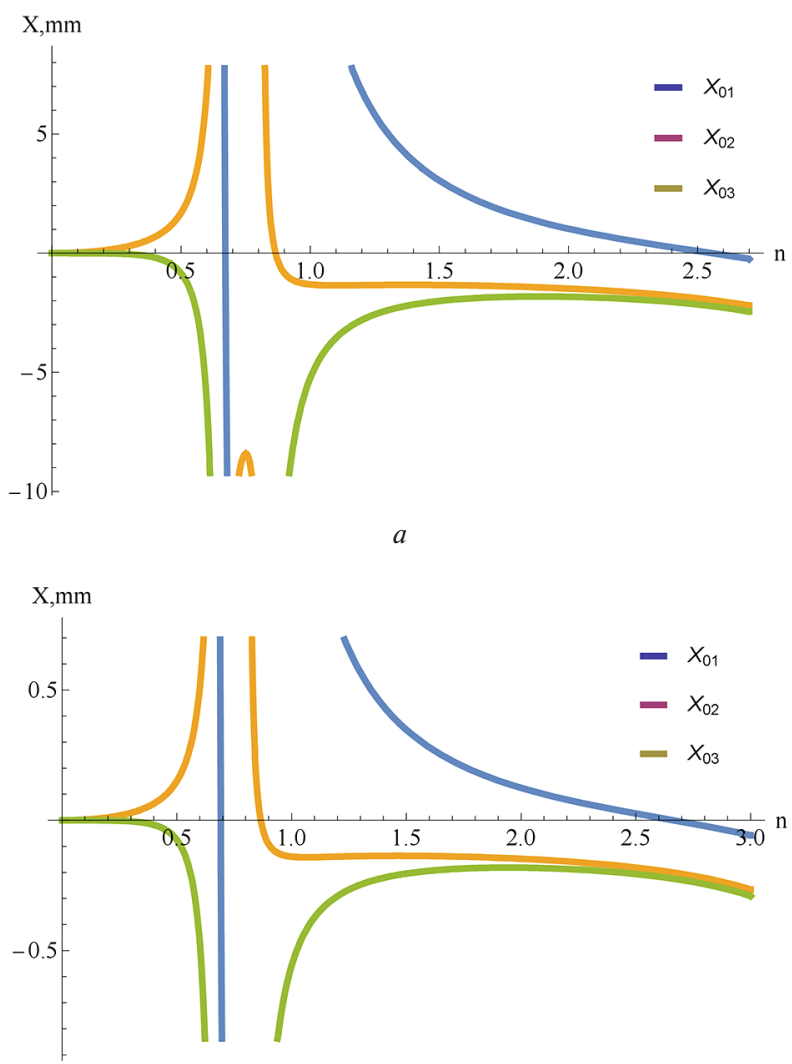

$b$

Fig. 2. Characteristics of the vibration amplitude as a function of the coefficient $n$ :

$a-\omega_{0}=104.67 \mathrm{rad} / \mathrm{s} ; b-\omega_{0}=314 \mathrm{rad} / \mathrm{s}$ 
coefficients for the specified operation mode of the crusher system.

Using equations (2-4), the characteristics of the vibration amplitude as a function of the coefficient $\mathrm{n}$ were determined.

The vibration amplitudes of the crushing plates depend not only on the elasticity of elastic connecting elements but also on the weights of the vibrating elements. This effect was analyzed at the further study stage.

When selecting the relation between the weights $m_{2}$ and $m_{3}$, the parameter $\mathrm{m} 1$ value is set as a constant value depending on the design of the crusher system. The $c_{1}$ and $c_{2}$ parameter values are determined with consideration for equations (2-4). To determine the optimal relation between the weights of the vibrating elements, the following equations are used

$$
\begin{gathered}
m_{2}=\left(N_{23} k_{23}\right) /\left(1+k_{23}\right) ; \\
m_{3}=N_{23} /\left(1+k_{23}\right),
\end{gathered}
$$

where $N_{23}=m_{2}+m_{3} ; k_{23}=m_{2} / m_{3}$.

On the basis of these equations, the characteristics of the vibration amplitude as a function of the $k_{23}$ ratio were determined for different vibration frequency ranges (Fig. 3).

The same method is used for determining the optimal relation between weights $\mathrm{m}_{2}$ and $\mathrm{m}_{1}$.

The characteristics of the vibration amplitudes of the crushing plates as a function of the excitation force frequency are presented in Fig. 4.

When the vibratory jaw crusher operates, provided that a centrifugal vibration exciter is used for generating vibrations, the horizontal vibrations are accompanied by vertical vibrations. Vertical vibrations are not required for crushing material in the crushing chamber but have a positive effect on the crusher productivity. Additionally, when vertical vibrations are present, there is a necessity to provide sufficient vibration isolation of the crusher foundation. For this purpose, an addi-
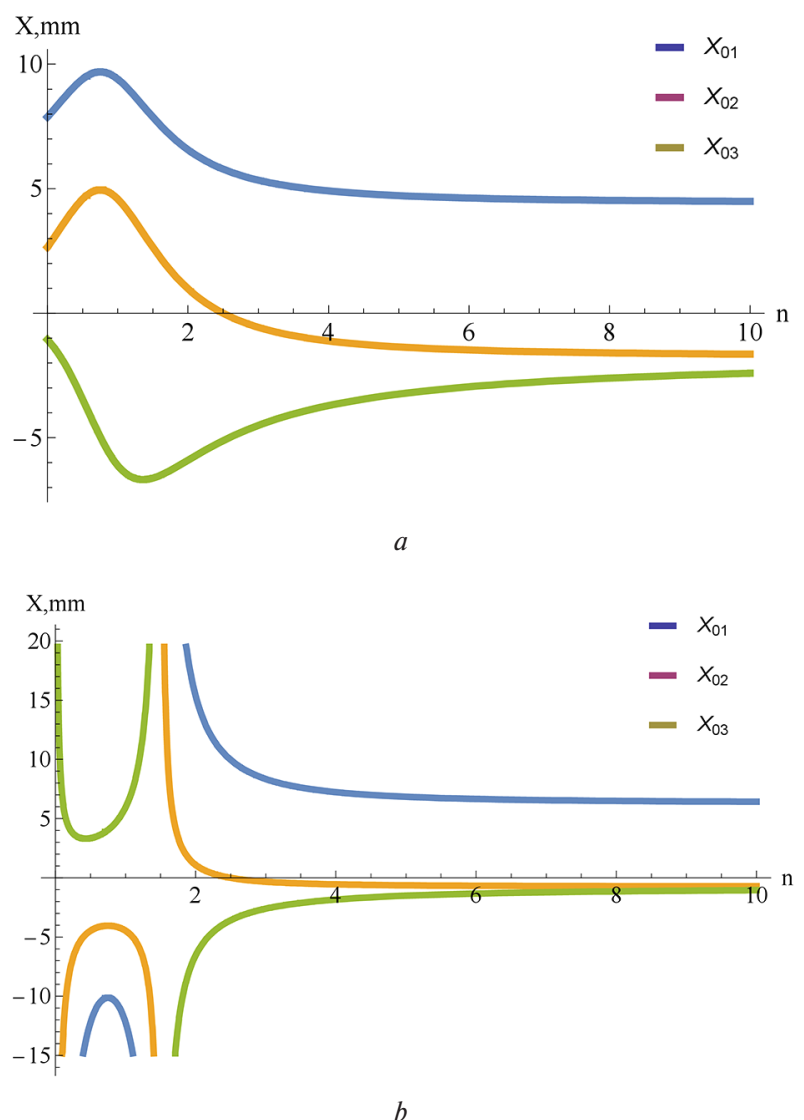

Fig. 3. Characteristics of vibration amplitude as a function of the $k_{23}$ weight ratio:

$a-\omega_{0}=104.67 \mathrm{rad} / \mathrm{s} ; b-\omega_{0}=314 \mathrm{rad} / \mathrm{s}$

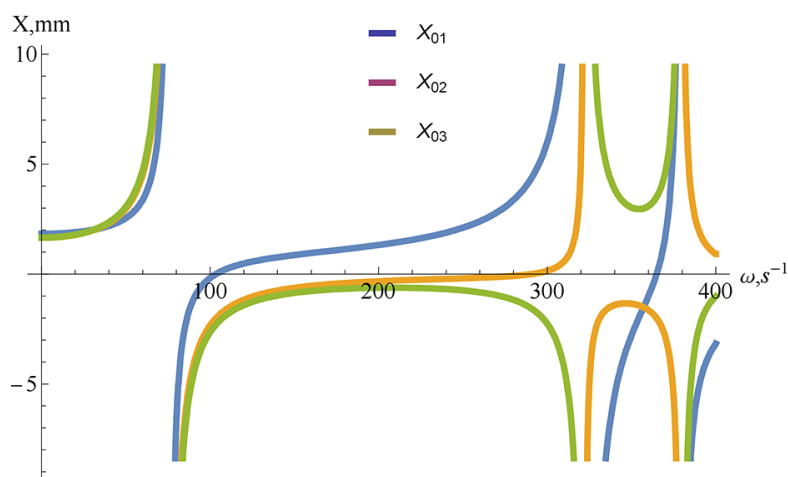

$a$

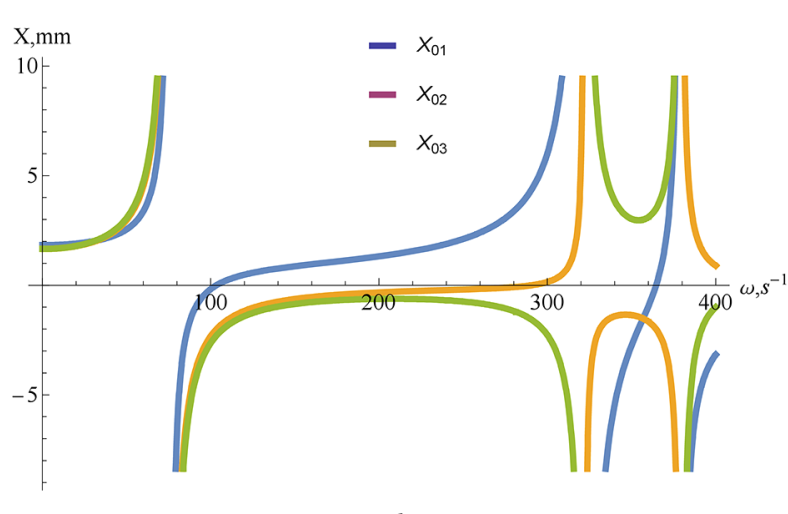

Fig. 4. Amplitude-frequency characteristics of the crusher at $\omega_{0}=314 \mathrm{rad} / \mathrm{s}$ :

$a$-operation without material in the crushing chamber; $b-o p-$ eration with material in the crushing chamber

tional elastic connecting element $c_{i s}$, for protecting the foundation against vibrations is provided.

So, in calculations concerning the vibration isolation system of the crusher, it is necessary to fulfill the following requirements to the system: 1 . The system must provide effective vibration isolation. 2 . The system must limit the amplitude of vertical vibrations according to the specified amplitude value.

The efficiency of vibration isolation is characterized by the following vibration transfer factor [11]

$$
k_{n}=\left(1 /\left(\omega / \omega_{0}\right)^{2}-1\right),
$$

where $\omega$ is the frequency of forced vibrations $(\mathrm{rad} / \mathrm{s}) ; \omega_{0}$ is the frequency of natural vibrations ( $\mathrm{rad} / \mathrm{s})$.

The degree of vibration isolation is characterized by the isolation efficiency coefficient $k_{\text {eff: }}$. The dependence of the isolation efficiency coefficient on dimensionless parameters $k_{z}=$ $=\omega / \omega_{0}$ and $k_{v}=b /\left(2 \sqrt{\left(c_{i s} m\right)}\right)$ is the following [11]

$$
k_{\text {eff }}=\sqrt{\frac{1+4 k_{z}^{2} k_{v}^{2}}{\left(1-k_{z}^{2}\right)^{2}+4 k_{z}^{2} k_{v}^{2}}} .
$$

The effective vibration isolation is ensured if $k_{\text {eff }} \leqslant 1$.

The most used vibration isolation elements are steel spring, rubber, and rubber-metal dampers [11].

Spring dampers should be used at vibration frequencies below $33 \mathrm{~Hz}$ and significant vibration amplitudes.

The spring dampers used in crushers with vertical vibrations have, predominantly, two springs. Such spring dampers are described by the following equations

$$
\begin{aligned}
& c_{1}=\left(c_{s} / 2\right)+\left(m_{n} g / 2 x_{r}\right) ; \\
& c_{t}=\left(c_{s} / 2\right)-\left(m_{n} g / 2 x_{r}\right),
\end{aligned}
$$


where $c_{1}, c_{t}$ are the elasticity of the lover and upper springs, correspondingly; $c_{s t}$ is the total elasticity of the spring set; $m_{n}=$ $=m_{\text {total }} / n_{s p}$ is the weight of the spring set; $n_{s p}$ is the number of spring sets; $x r$ is the resonance vibration amplitude.

When selecting the spring damper, it is necessary to consider that $c_{1} / c_{t}=3$. When analyzing equation (8), it is evident that there can be negative values in calculating the elasticity of the upper spring. For the experimental vibratory crusher, the characteristics of elasticity of the upper spring as a function of resonance vibration amplitude are presented in Fig. 5. The average resonance frequency in the operating frequency range is specified as $\omega=104.67 \mathrm{rad} / \mathrm{s}$.

As is stated above, vertical vibrations have a significant effect on the crusher productivity. This effect is evident as the distance which is traveled by the processed material in the crushing chamber for a time interval required for the crushing plates to be separated. The rotation frequency of the crusher unbalance shaft should be inversely proportional to the said distance.

The distance is determined as follows

$$
l_{1}=\frac{g t_{\text {fall }}^{2}}{2}+\frac{F_{0}}{m_{c r} \omega^{2}},
$$

where $m_{c r}$ is the crusher weight; $F_{0}$ is the excitation force; $g$ is the gravitational acceleration; $t_{\text {fall }}$ is the period during which the material in the crushing chamber is in free falling state.

In another form, the equation for the distance is the following

$$
l_{1}=\frac{g(\sin [\alpha]-\mu \cos [\alpha])}{4 f}+\frac{F_{0}}{m_{c r} \omega^{2}},
$$

where $\mu$ is the friction coefficient; $f$ is the vibration frequency $(\mathrm{Hz}) ; \alpha$ is the material entrance angle.

With consideration for the similarity coefficients and the above-mentioned study tasks, the physical model of a vibratory jaw crusher for experimental studies was developed [12].

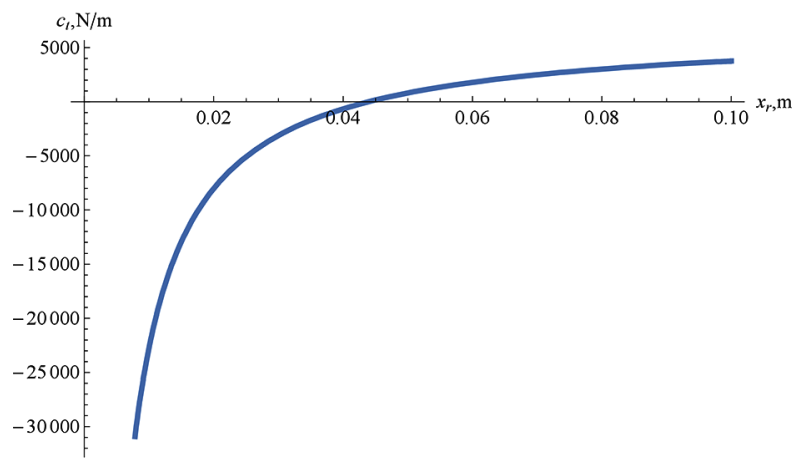

$a$

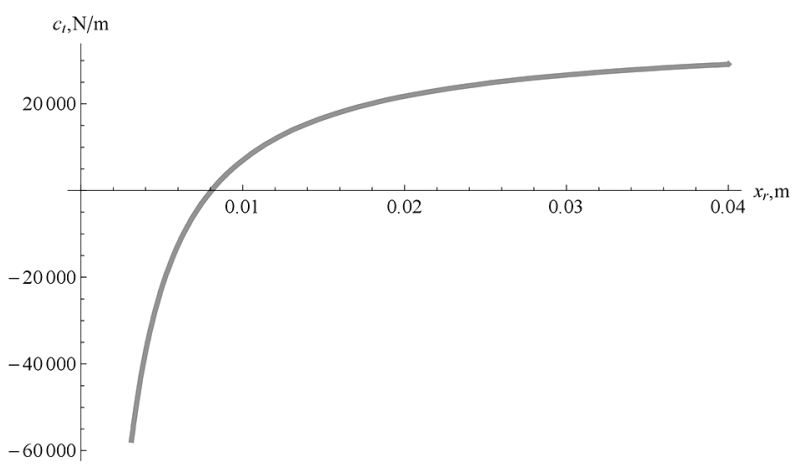

$b$

Fig. 5. Characteristics of the elasticity of the upper spring as a function of resonance vibration amplitude: $a-\omega / \omega_{0}=7 ; b-\omega / \omega_{0}=3$
When performing the experimental studies, the physical simulation method for engineering systems was used.

To determine the characteristics of the experimental crusher and the parameters of the crusher operational process, electronic measuring equipment was used. The displacements of the elastic elements were measured by resistive strain sensors because such a measurement method is the most appropriate for swift-flowing processes.

The measurement data were used for determining the regression coefficients and equations for the crusher. Determined were the design matrix with consideration for the specified number of the crusher input variables, confidence interval, statistical significance of the regression coefficients, error mean square, and model validity. To determine the model validity, the Fisher method was used. The number of studies according to the specified accuracy and reliability of measurement data was determined with consideration for the calculated standard deviation and mathematical expectation of the crusher variable values.

The experimental studies were performed in order to obtain data required for plotting characteristics describing the effect of the basic parameters of the crusher with three vibrating elements on the operational process when processing material with low and medium hardness. The studies were performed in accordance with the above-mentioned methods. As material to be processed, ceramic material was used.

The results of the studies for determining the effect of vibration frequency on the vibration amplitude of the third vibrating element of the crusher, with consideration for the specified parameters of the excitation force and elasticity coefficients of the spring dampers, are presented in vibration records.

The vibration records obtained for the crusher in the crushing chamber are presented in Fig. 6.

The characteristics in Fig. 2 demonstrate that the optimal value of the parameter $\mathrm{n}$ is $0.6 \leq n \leq 1$. If $1 \leq n<2.5$, the effective operating range of the crusher is narrow and shifts to higher frequencies. At this study stage, the operating mode of the crusher is efficient if the three conditions in connection with equations $(2,3)$ are fulfilled.

When analyzing the characteristics in Fig. 3, it was determined that the optimal value of the coefficient $k_{23}$ is in the range $0<k_{23} \leq 2.5$ for resonance frequency $104.67 \mathrm{rad} / \mathrm{s}$, and in the range $1.5<k_{23} \leq 2.45$ for resonance frequency $\omega_{0}=$ $=314 \mathrm{rad} / \mathrm{s}$.

The maximum value of the vibration amplitude of the third vibrating element at resonance frequency $\omega_{0}=$ $104.67 \mathrm{rad} / \mathrm{s}$ is at $k_{23}=1.3$, and the maximum values of the vibration amplitudes of the first and second vibrating elements at resonance frequency $\omega_{0}=104.67 \mathrm{rad} / \mathrm{s}$ are at $k_{23}=$ $=0.75$. At resonance frequency $\omega_{0}=314 \mathrm{rad} / \mathrm{s}$, the maximum values of the vibration amplitudes of all the vibrating elements are at $k_{23}=1.5$.

After determining the ranges of rational values of the $n, k_{23}$, and $k_{21}$ parameters, the amplitude-frequency characteristics of the crusher were determined on the basis of equations $(2,3)$ (Fig. 4).

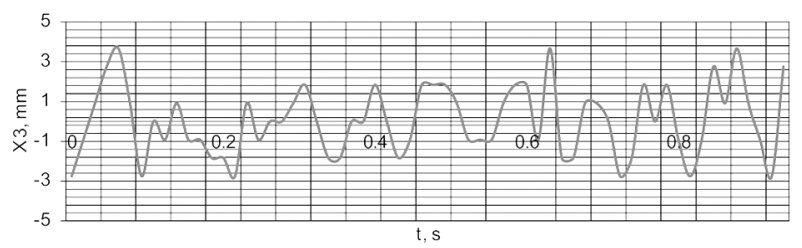

Fig. 6. Vibration record for the third vibrating element of the crusher with material in the crushing chamber: $\omega_{0}=104.67 \mathrm{rad} / \mathrm{s} ; \mathrm{F}-4111 \mathrm{~N} ; c_{2}=234438 \mathrm{~N} / \mathrm{m}$ 
According to these characteristics, it was determined that the efficient operating mode of the crusher is possible at the second resonance frequency and in the range between the second and third resonance frequencies. If the design resonance frequency $\omega 0$ increases, the frequency range for efficient operation of the crusher shifts to higher frequencies. The efficient frequency ranges for the corresponding resonance frequencies $\omega_{0}$ is the following: $1.97 \mathrm{rad} / \mathrm{s}<\omega<121 \mathrm{rad} / \mathrm{s}, 129 \mathrm{rad} / \mathrm{s}<\omega<$ $<200 \mathrm{rad} / \mathrm{s}$ at $\omega_{0}=104.67 \mathrm{rad} / \mathrm{s} ; 2.291 \mathrm{rad} / \mathrm{s}<\omega<322 \mathrm{rad} / \mathrm{s}$, $365 \mathrm{rad} / \mathrm{s}<\omega<400 \mathrm{rad} / \mathrm{s}$ at $\omega_{0}=314 \mathrm{rad} / \mathrm{s}$.

In order to ensure the operation of the crusher with the values of the elasticity coefficients that were calculated for natural vibration frequencies 104.67 and $157 \mathrm{rad} / \mathrm{s}$, it is necessary to increase, in lower frequency ranges, the weights of the crusher vibrating elements. The increased weights must not exceed the limit values at which the crusher design is economically inadvisable.

As is shown in Fig. 5, $a$, the actual elasticity values of the upper spring correspond to the range of resonance vibration amplitudes $x \in(0.044, \infty)$. Accordingly, in the resonance mode, there are vertical vibrations with high amplitudes which are not acceptable in the process of crushing material. If $\omega / \omega_{0}=3$ (Fig. $5, b$ ), the resonance vibration amplitudes are in the range $x \in(0.008, \infty)$. In this case, the amplitudes are far lower, but the efficiency of the spring damper is reduced.

Theoretical studies were also performed to determine the distance which is traveled by processed material in the crushing chamber for a time interval required for the crushing plates to be separated. According to the study results, equation (10) was set up for the distance. This equation allows the number of operational cycles required for crushing material to be determined and. as a result, to optimize power consumption.

The most efficient frequency range is the range $14.5 \mathrm{~Hz}<$ $<f<26 \mathrm{~Hz}$ between the second resonance frequency and the third resonance frequency. This range was analyzed at three characteristic frequencies: at frequency $f=16.7 \mathrm{~Hz}$ close to the resonance frequency and at frequencies $f=19$ and $f=$ $=22 \mathrm{~Hz}$ distant from the resonance frequency. The maximum vibration amplitude of the third vibrating element at frequency $f=16.7 \mathrm{~Hz}$ is $5 \mathrm{~mm}$. The vibration amplitudes of the vibrating elements of the crusher at frequencies between the second and third resonance frequencies decrease at approach to frequency $f=22 \mathrm{~Hz}$ and then increase at approach to frequency $f=26 \mathrm{~Hz}$.

The characteristic in Fig. 6 describe the vibration amplitude of the third vibrating element of the crusher.

Material crushing is ensured in the frequency range $14.5<$ $<f<26 \mathrm{~Hz}$. The crusher efficiency slightly decreases at frequency close to $f=22 \mathrm{~Hz}$ due to the decrease in the vibration amplitudes of the second and third vibrating elements and due to the decrease in the amplitude of vertical vibrations of the crusher casing, resulting in the increase in the time interval during which material is present in the crushing chamber. If the crusher operating frequency is $16.7 \mathrm{~Hz}$, the maximum vibration amplitude of the third vibrating element decreases to $3.6 \mathrm{~mm}$ (Fig. 6).

In studying the effect of the elasticity coefficients $c_{1}$ and $c_{2}$ of the elastic elements on the crushing process, the following characteristic features were detected. When the elasticity coefficient $c_{2}$ increases, the efficient operating range of the crusher shifts to higher vibration frequency values. This feature is caused by the shift of the resonance frequency to higher vibration frequency. But excessive increase or decrease in the elasticity coefficient has a negative effect on the crusher operation. For example, if the elasticity coefficient $c_{2} \geq 3538800 \mathrm{~N} / \mathrm{m}$, the crusher operation in the frequency range $f<25 \mathrm{~Hz}$ is inefficient. In this case, it is necessary to increase the weights of the crusher vibrating elements and the excitation force. If the value of the elasticity coefficient $c_{2}$ is too low, the efficiency of transferring energy from the vibration exciter to the third vibrating element decreases, and the conditions according to basic equation systems $(2,3)$ are not fulfilled. If the value of the elasticity coefficient $c_{1}$ increases, the efficient operation range of the crusher shifts to zero. If the value of the elasticity coefficient $c_{1}$ is too high, the crusher system with three vibrating elements converts into a system with two vibrating elements. If the value of the elasticity coefficient $c_{1}$ is too low, the crusher system is in unstable state, resulting in a negative effect on the crushing process.

Conclusions. Developed are the physical and mathematical models of a vibratory jaw crusher. The models include elastic and inertial properties, power characteristics, and dimensional parameters of the crusher-material system. The basic subject in studying the crusher-material system is the system amplitude-frequency characteristics. The study results provide the possibility to determine the values of the system elasticity coefficients as a function of vibration frequency, which are required for determining the optimal relation between the parameters of the crusher vibrating elements. The values of the vibration amplitudes of the crusher vibrating elements are the highest if the coefficient $\mathrm{n}$ related to the ratio between elasticity and vibration frequency is in the range $0.6 \leq n \leq 1$. Efficient crushing of materials is possible in the vibration frequency range $14.5<f<26 \mathrm{~Hz}$. Determined are the values of the coefficients $k_{21}$ and $k_{23}$ that are required for determining the optimal relation between the parameters of the crusher vibrating elements.

\section{References.}

1. Gursky, V.M., Lanets, O.S., Shpak, Y.V., \& Lozynsky, V.I. (2011). Influence of nonlinearity of electromagnetic drive force on dynamics of vibrating machines. Vibratsii v tehnitsi ta tekhnologiiakh, 1(61), 25-31

2. Turkin, V. Ya., Tyagushev, S. Yu., \& Shonin, O. B. (2014). Increasing the technological parameters of a vibrating jaw crusher by means of automated electric drive. Mining informational and analytical bulletin (scientific and technical journal), 2, 130-136.

3. Sablin, R. A. (2014). Experimental studies on the operating mode of a vibratory jaw crusher with an inclined crushing chamber. Mining informational and analytical bulletin (scientific and technical journal), 1, 406-409.

4. Wolny, S. (2013). Dynamic behavior of a vibrating jaw crusher for disintegration of hard materials. Archive of metallurgy and materials, 58(3), 1-4. https://doi.org/10.2478/amm-2013-0092.

5. Sidor, J., \& Mazur, M. (2013). The use of a vibratory crusher in processes of very fine crushing of raw materials and industrial waste ceramics. Ceramic Materials, 65(1), 71-75.

6. Sidor, J., \& Mazur, M. (2014). Examination of crushing rock crystal in a vibratory jaw crusher. Ceramic Materials, 66(1), 32-36. Retrieved from http://yadda.icm.edu.pl/yadda/element/bwmeta1.element.baztech-98f90d2c-8bef-48e5-bc49-70ecc04e74d4.

7. Zhang, J., \& Wang, L. (2014). Optimization design of vibratory jaw crusher with double cavities based on MATLAB. Trans Tech Publications. https://doi.org/10.4028/www.scientific.net/AMR.945949.596.

8. Shishkin, E. V., \& Kazakov, S.V. (2017). Application of vibratorypercussion crusher for disintegration of supertough materials. IOP Conf. Series: Earth and Environmental Science, 87. https://doi. org/10.1088/1755-1315/87/2/022018.

9. Jiang, J., Liu, Sh., \& Wen, B. (2014). Dynamic characteristics of vibrating cone crusher with dual exciters considering material effects. Trans Tech Publications. https://doi.org/10.4028/www.scientific. net/AMR.902.148.

10. Nazarenko, I. I., \& Mishchuk, E.O. (2014). Studies on the working process of destruction in a grinding chamber of the vibrating jaw crusher. Mining, construction, road and reclamation machines, 84, 55-63.

11. Dyrda, V. I., Lisitsa, N. I., \& Lisitsa, N. N. (2013). Development of vibration isolators for mining machines. Geotechnical mechanics, $113,116-125$

12. Nazarenko, I. I., \& Mishchuk, E. O. (2019). Research on the dynamics of a vibratory jaw crusher of bilateral action. Mining, construction, road and reclamation machines, 94, 5-15. https://doi. org/10.32347/gbdmm2019.94.0101. 


\section{Визначення раціональних режимів роботи вібраційної щокової дробарки}

Є. О. Мімук, І. І. Назаренко, Д. О. Мішук

Київський національний університет будівництва і архітектури, м. Київ, Україна, e-mail: mischuk.ieo@knuba.edu.ua

Унаслідок постійного розвитку будівельної галузі постає питання у створенні нових або модернізації старих зразків техніки. Застосування ударного характеру дії дробильних щік на матеріал є найбільш перспективним напрямом розвитку дробильних машин.

Мета. Розробка математичної моделі вібраційної шокової дробарки, дослідження робочого процесу на основі математичної моделі для створення нової конструкції.

Методика. Визначення робочого процесу дробарки грунтується на основних положеннях теорії механічних коливань і теорії суцільних середовищ. У рівняннях руху дробарки матеріал ураховується на основі дискретної моделі континуальним параметром

Результати. Побудована фізична модель, на основі якої складені рівняння руху дробарки, що включають три основні умови ефективної роботи: 1) пружність другої пружної системи повинна бути більше або рівною силі дроблення; 2) перша та третя маси повинні коливатися у фазі, а друга - у протифазі; 3) сумарне перемішення другої та третьої дробильних щік має забезпечувати руйну- вання матеріалу. Наведені та проаналізовані графіки впливу коливальних мас і коефіцієнтів пружності пружних систем на їх амплітуду коливань. На основі рівнянь руху дробарки та з урахуванням раціональних значень параметрів мас і коефіцієнтів пружності пружних систем побудована амплітудо-частотна характеристика роботи дробарки за різних частотних діапазонів. Складено рівняння, що визначає шлях, який проходить матеріал за час відходу дробильних плит. Представлені графіки залежності вертикальної амплітуди коливань корпусу дробарки від пружності ізоляційної пружної системи й надані рекомендації із вибору й розрахунку віброізоляції.

Наукова новизна. Представлена математична модель дослідної вібраційної шокової дробарки та графіки експериментальних досліджень, на основі яких надані рекомендації щодо вибору енергоефективних режимів роботи дробарки.

Практична значимість. Знання раціональних значень частотних діапазонів роботи досліджуваної вібраційної щокової дробарки дає можливість у подальшому визначити оптимальні значення затрачуваної електроенергії та продуктивності при дробленні матеріалів різної міцності.

Ключові слова: вібраційна щокова дробарка, коефіцієнт пружності, енергоефективність, частота коливань, збурювальне зусилля

Recommended for publication M.P. Kuzminets, Doctor of Technical Sciences. The manuscript was submitted 26.01.21. 